\title{
Withdrawn: Impact of the NHS stop smoking services on smoking prevalence in England: a simulation modelling evaluation
}

Song F, Elwell-Sutton T, Naughton F. Impact of the NHS stop smoking services on smoking prevalence in England: a simulation modelling evaluation. Tob Control 2018. doi:10.1136/ tobaccocontrol-2018-054586. [Epub ahead of print 05 Dec 2018].

This article has been withdrawn from Tobacco Control while it undergoes further editorial review.

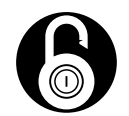

\section{OPEN ACCESS}

Open access This is an open access article distributed in accordance with the Creative Commons Attribution Non Commercial (CC BY-NC 4.0) license, which permits others to distribute, remix, adapt, build upon this work noncommercially, and license their derivative works on different terms, provided the original work is properly cited, appropriate credit is given, any changes made indicated, and the use is non-commercial. See: http://creativecommons.org/licenses/by-ncl 4.0\%.

(C) Author(s) (or their employer(s)) 2018. Re-use permitted under CC BY-NC. No commercial re-use. See rights and permissions. Published by BMJ.

Tob Control 2018;0:1. doi:10.1136/tobaccocontrol-2018-054586.wit

(A) Check for updates 